\title{
The competitiveness of natural rubber by exporting countries in the global market
}

\author{
Imade Yoga Prasada ${ }^{1}$ and Aura Dhamira ${ }^{2}$ \\ ${ }^{1}$ Study Program of Agribusiness, Faculty of Science and Technology, Universitas Putra Bangsa, Jl \\ Ronggowarsito No. 18 Kebumen 54361, Indonesia \\ ${ }^{2}$ Graduate Student, Faculty of Agriculture, Universitas Gadjah Mada
}

\begin{abstract}
The increased in global demand for natural rubber commodities opens opportunities for natural rubber exporting countries to compete with their competitors. Competitiveness is the main provision to be able to compete well. Therefore, this research was conducted to determine the export competitiveness of natural rubber by exporting countries and to determine the position of the natural rubber commodity of each exporter in the global market. The research data were secondary data sourced from Trademap in the period of 2001-2019. Furthermore, the data were analyzed using revealed comparative advantage (RCA) index and export product dynamics (EPD) methods. The results of the analysis show that Thailand, Indonesia, and Malaysia are able to produce natural rubber commodities with strong competitiveness. EPD analysis also shows that Thailand, Indonesia, and Malaysia respectively have a rising star, lost opportunity, and retreat positions in natural rubber commodities traded on global markets.
\end{abstract}

\section{Introduction}

Natural rubber commodity is an important raw material for various industries in the world. This also encourages the increasing demand for natural rubber from year to year. The data shows that the world's demand for natural rubber has increased relatively by 61 million USD per year [1]. The demand for rubber commodities is one of the determinants of the size of exports carried out by exporting countries [2]. The high demand for natural rubber in the world opens opportunities for natural rubber exporting countries to be able to compete in meeting this demand. Indonesia is listed as one of the world's exporters of natural rubber. Indonesia currently ranks first, followed by Thailand and Malaysia in second and third place. Indonesia controls the world's natural rubber market share of 42.53 percent on average, while Thailand and Malaysia have natural rubber market shares of 15.16 percent and 17.83 percent, respectively. The three countries have a fairly-large market share, thus giving rise to intense competition in the global trade of rubber commodities. Although Indonesia has the largest share of natural rubber in the world on average, data shows that the share of Indonesia's natural rubber exports is relatively weak from year to year. This can also be seen from the share of Malaysian natural rubber exports. The share of Indonesia's natural rubber exports tended to decline by 0.85 percent per year, while Malaysia experienced a relative decline of 1.45 percent per year. However, at the same time, Thailand's share of natural rubber exports tended to increase by 1.65 percent per year. 
Each natural rubber exporting country targets different export destination countries. The main destination countries for Indonesia's natural rubber exports are the United States of America, Japan, and China, while Thailand is China, the United States of America, and Japan, then Malaysia is China, Germany, and the United Arab Emirates. The export destinations of natural rubber for Indonesia, Thailand, and Malaysia tend to be identical. This will encourage intense competition against the three countries in order to win the competition in the global market of natural rubber commodity.

The competition between natural rubber exporting countries is inseparable from the indicators of the competitiveness of the products. Several studies related to the export competitiveness of natural rubber have been carried out in various countries and various case studies. Studies in Thailand, Indonesia, Malaysia, and Vietnam using the RCA (Revealed Comparative Advantage) index in 2010-2014 show that Indonesia has higher export competitiveness than Thailand, Malaysia, and Vietnam [3]. Other research using the ECI (Export Competitiveness Index) indicator shows that the competitiveness of Indonesia's natural rubber exports has decreased, which is indicated by an ECI value of less than 1, but at the same time Thailand's export competitiveness is experiencing an increasing trend with a ECI value greater than 1 [4]. Furthermore, research related to the export of Indonesian natural rubber commodities in the global market shows that Indonesia still has a high comparative advantage and competitive advantage $[5,6]$.

The export competitiveness of natural rubber commodities in exporting countries is dynamic, meaning that changes occur in each period. This gives a signal that competition in maintaining and seizing market share for natural rubber commodities in the global market continues. Therefore, this research was conducted to determine the export competitiveness of natural rubber commodities by the three main exporters in the global market. This research not only determines the export competitiveness of natural rubber by the main exporting countries but also determines the position of the natural rubber commodities of each exporting country in the global market. This position can show the export prospect of natural rubber produced by each exporting country.

\section{Materials and methods}

The data in this study were secondary data sourced from the Trademap for the period 2001 to 2019. Natural rubber exporting countries in this study were Indonesia, Thailand, and Malaysia. The three countries were selected using a purposive sampling method with the consideration that Indonesia, Thailand, and Malaysia are the 3 largest natural rubber exporters in the global market. In addition, this study uses a 6 digits HS code, namely 400122 - Technically specified natural rubber "TSNR". TSNR is used as a commodity studied in this research due to the very high share of natural rubber exports with TSNR specifications. Indonesia's TSNR exports reached 97.13 percent of the total natural rubber exports. In addition, Thailand's TSNR exports reached 52.30 percent of total natural rubber exports, while Malaysia was recorded as having a TSNR export share of 94.23 percent of total natural rubber exports in 2019 [1]. This value shows the majority of natural rubber exports in the global market included in the TSNR specification.

This study used a revealed comparative advantage (RCA) index to determine the export competitiveness of natural rubber by each exporting country. Revealed comparative advantage is a method that can be used to determine the comparative advantage of a particular commodity relative to other countries [7]. RCA is currently a method that is widely used to measure comparative advantage in international trade [8]. Comparative advantage in the RCA method is calculated by using data on the export trade flows of a country against certain commodities in certain markets $[9,10]$. RCA can be written using the following equation $[11,12]$ : 


$$
R C A_{i j}=\left(X_{i j} / X_{t}\right) /\left(X_{w j} / X_{w t}\right)
$$

$R C A_{i j}$ is revealed comparative advantage for country i in product $j, X_{i j}$ is the value of the country's export of product $j$ to the global market, $X_{t}$ is the value of country i's total exports to the global market, $X_{w j}$ is the value of world export of product $j$, and $X_{w t}$ is the value of world total exports. The RCA value will be in the value interval between 0 and infinitely positive $(0 \leq \mathrm{RCA} \leq+\infty)$ [13], [14]. RCA values can be grouped into 4 categories, namely [15]: 1 . No comparative advantage $(0<\mathrm{RCA} \leq 1), 2$. Week comparative advantage $(1<\mathrm{RCA} \leq 2), 3$. Moderate comparative advantage $(2<\mathrm{RCA} \leq 4)$, and 4 . Strong comparative advantage (4 $<$ RCA).

Beside that to determine the position of the natural rubber commodity of each exporting country in the global market, it can be done using the export product dynamics (EPD) method. EPD is composed of a matrix consisting of growth in market share of total exports and growth in product market share. EPD can be determined using the following equation [16]:

$\mathrm{X}$-axis (Growth in market share of total exports of commodity i):

$$
\frac{\sum_{t=1}^{t}\left({ }^{X_{i j}} / W_{i j}\right)_{t} \times 100 \%-\sum_{t=1}^{t}\left({ }^{X_{i j}} / W_{i j}\right)_{t-1} \times 100 \%}{t}
$$

$\mathrm{Y}$-axis (Growth in product market share):

$$
\frac{\sum_{t=1}^{t}\left(X_{t} / W_{t}\right)_{t} \times 100 \%-\sum_{t=1}^{t}\left(X_{t} / W_{t}\right)_{t-1} \times 100 \%}{t}
$$

$\mathrm{X}_{\mathrm{ij}}$ is the export value of commodity i from country $\mathrm{j}, \mathrm{W}_{\mathrm{ij}}$ is the export value of commodity $i$ from countries in the world, $X_{t}$ is the total value of country $j$ 's exports to the global market, $\mathrm{W}_{\mathrm{t}}$ is the total export value of the world's countries in the global market, and $\mathrm{t}$ is the number of years of analysis. EPD is divided into 4 categories of commodity positions in a market [17], [18]. This division can be seen in Table 1.

Table 1. Export Product Dynamics (EPD) market position matrix

\begin{tabular}{|l|l|l|}
\hline \multicolumn{1}{|c|}{$\begin{array}{c}\text { Share of Country's Export in } \\
\text { World Trade (X) }\end{array}$} & \multicolumn{2}{c|}{ Share of Product in World Trade (Y) } \\
\cline { 2 - 3 } & Rising (dynamic) & Falling (stagnant) \\
\hline Rising (competitiveness) & Rising Star & Falling Star \\
\hline Falling (non-competitiveness) & Lost Opportunity & Retreat \\
\hline
\end{tabular}

\section{Result and discussion}

Natural rubber is one of the export commodities that has an important role for the economy of a country. Natural rubber is the raw material for various processing industries. Therefore, the demand for natural rubber in the world market tends to increase from year to year. Data sourced from the Trademap shows that the demand for natural rubber in the world is relatively increasing by 614,374 thousand USD per year (Fig. 1). In addition, the demand for natural rubber reached its highest point in 2011 at 3,3221,392 thousand USD. This has prompted many countries, especially in tropical areas such as Indonesia, Malaysia, or Thailand, to meet the demand for natural rubber. 


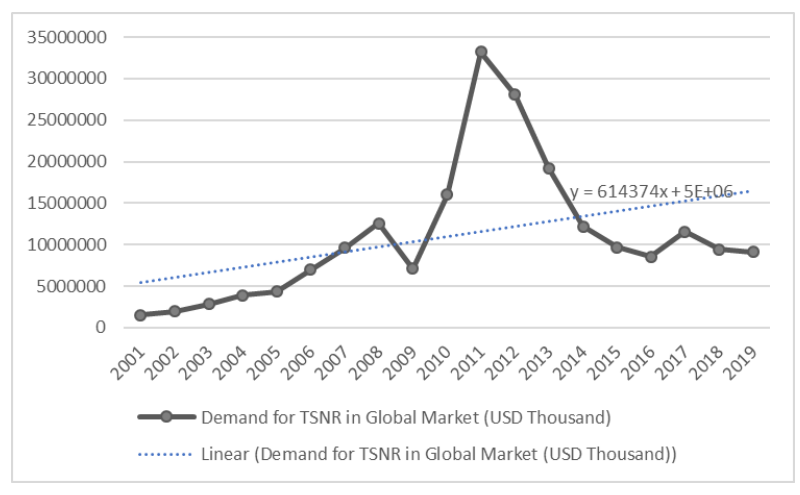

Fig. 1. The Demand for Natural Rubber in the Global Market

The results of the analysis show that the average RCA index for Indonesian natural rubber commodities in the global market in the period of 2001-2019 is 47.17. This value is greater than 4, thus indicating that Indonesia's natural rubber commodity in the global market is highly competitive. Despite its strong competitiveness, the Indonesian RCA index fluctuates quite a bit (Fig. 2a.). The highest Indonesian RCA index in the period of 2001-2019 occurred in 2004 amounting to 64.79. In contrast, Indonesia's RCA index reached its lowest point in 2012 with a value of 26.30 . Overall. Indonesia's RCA index tends to decrease by 1.31 per year.

The development pattern of Indonesia's competitiveness is similar with Malaysia's. The RCA index for Malaysian natural rubber commodities has a negative trend, meaning that the competitiveness of Malaysian natural rubber exports has decreased from year to year by 0.98 . Malaysia's RCA index reached its highest point in 2005 with a value of 23.75 , while the lowest Malaysian RCA index value occurred in 2012 reaching 6.86. The average RCA index value for Malaysian natural rubber was 13.35. This value is greater than 4 , meaning that the export of Malaysian natural rubber commodities in the global market also has strong competitiveness.

The movement pattern of the export competitiveness of natural rubber commodities from Indonesia and Malaysia is quite identical, seen from the highest and lowest points of export competitiveness which are the same and close to each other. This pattern of movement is opposite to the pattern of demand for natural rubber which is formed in the global market. The highest demand for natural rubber in the global market occurred in 2011 and 2012, while the lowest demand for natural rubber occurred in 2001. This could be due to the fact that in 2001 there were only a few countries that were able to become natural rubber producers, so the competition was looser. In addition, the natural rubber produced by Indonesia and Malaysia is still able to supply natural rubber demand in the global market. This case is different in 2011 and 2012 where the demand for natural rubber reached its highest point. In this position, Indonesia and Malaysia were unable to meet the world's demand for natural rubber, thus failing to maintain their export performance as in 2001. As a result, Thailand could take over the share of natural rubber exports. 


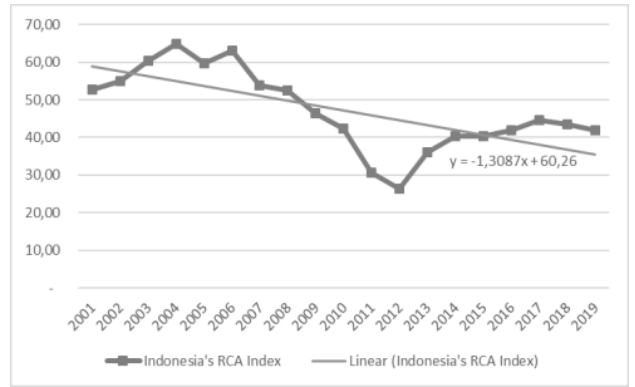

(a)

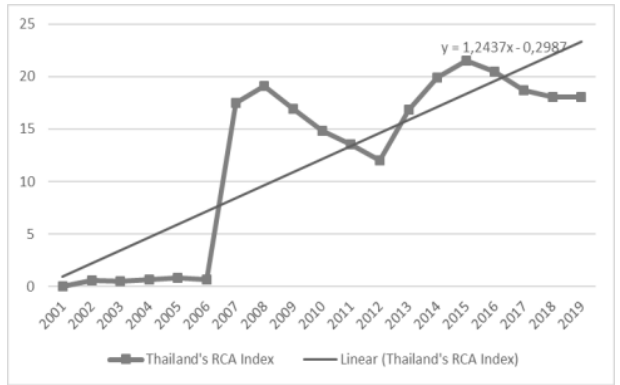

(b)

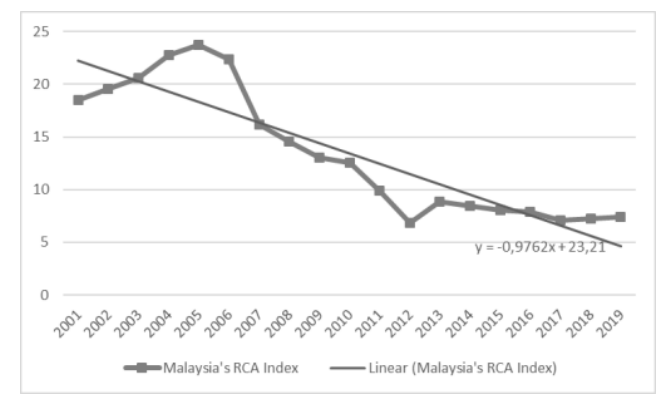

(c)

Fig. 2. (a) Development of Indonesia's RCA Index to Global Market; (b) Development of Thailand's RCA Index to Global Market; (c) Development of Malaysia's RCA Index to Global Market

The export competitiveness of Thailand's natural rubber commodities is in the category of strong competitiveness. This was supported by the RCA value of Thailand's natural rubber commodity in the global market which reached an average of 12.14. Thailand's RCA index value fluctuates greatly. The highest RCA index occurred in 2015 where the index value reached 21.51. In addition, the RCA value of Thailand's natural rubber commodity once touched its lowest point in 2001 which only reached 0.001 . Thailand is an exporting country with excellent export performance. This is reflected in the development of the export competitiveness of Thailand's natural rubber commodities, which originated in 2001 had an RCA that could not even reach 1 , but this value continued to increase slowly until it reached its highest level in 2015. Compared to Indonesia and Malaysia, Thailand has a positive trend of natural rubber competitiveness, meaning that the competitiveness of Thailand's natural rubber exports tends to increase from year to year. It was noted that the export competitiveness of Thailand's natural rubber commodities increased by 1.24 per year.

In addition to the competitiveness of natural rubber commodities by exporting countries with the RCA index, this study also was analyzed the position of natural rubber commodities produced by exporting countries in the global market. The analysis showed that the best export performance for natural rubber was Thailand, followed by Indonesia and Malaysia. Thailand has a positive EPD score, so it is included in the rising star category. These results indicate that Thailand's natural rubber commodity in the period of 2001-2019 experienced an increase in the market share of domestic products and at the same time there was an increase in the export market share of natural rubber commodities in the global market. Unlike Thailand, Indonesia has an EPD value that is included in the lost opportunity category. The lost opportunity category indicates that Indonesia has experienced a decline in the market share of natural rubber commodities in the global market, thus losing the opportunity to 
expand its market share. Indonesia's condition is still much better than Malaysia's. Malaysia is included in the retreat category, which means that there is a decline in the market share of Malaysian natural rubber products, both in the domestic product market and in the global market. This result reflects that Malaysia's natural rubber products are no longer desired by the market globally.

Table 2. EPD of Natural Rubber Commodity by Exporting Country

\begin{tabular}{|c|c|c|c|}
\hline Country & $\begin{array}{c}\text { Share of Country's } \\
\text { Export in } \\
\text { World Trade }\end{array}$ & $\begin{array}{c}\text { Share of Product in World } \\
\text { Trade }\end{array}$ & EPD \\
\hline Indonesia & $-0,72$ & 0,02 & $\begin{array}{c}\text { Lost } \\
\text { Opportunity }\end{array}$ \\
\hline Thailand & 3,45 & 1,25 & Rising Star \\
\hline Malaysia & $-4,53$ & $-0,63$ & Retreat \\
\hline
\end{tabular}

Overall, Indonesia, Thailand, and Malaysia are able to produce natural rubber commodities that are highly competitive in the global market with an RCA index greater than 4. At the same time, the EPDs of Indonesia, Thailand, and Malaysia are included in the category a lost opportunity, rising star, and retreat respectively. The two indicators show that Thailand has an optimistic market development for natural rubber commodities with an RCA value of more than 4 and an EPD in the rising star category, while Indonesia has a potential natural rubber commodity market development (RCA $>4$ and EPD in the lost opportunity category) and Malaysia has a less potential market development for natural rubber commodities with an RCA index value greater than 4 and EPD is included in the retreat category [19].

From the natural rubber exporting countries, Thailand had the best export performance, followed by Indonesia and Malaysia. Several reasons why Thailand was able to produce the best export performance of natural rubber commodities, namely first from the demand side. The world demand for natural rubber has increased relatively from year to year. Countries that are able to meet this demand can seize the market share of other countries. Second, in terms of harvested area, Thailand and Indonesia had a positive trend of harvested area for rubber, while Malaysia had a negative trend. Malaysia faces the challenge of the massive rubber plantations conversion into oil palm plantations to be able to develop the natural rubber industry. Malaysia noted that in 1980 the rubber planted area reached 1,998,200 hectares, but in 2012 it fell to 1,041,540 hectares [20]. However, in 2019 Malaysia's natural rubber harvested area increased again to 1,083,992 hectares [21]. This is driven by the increasing price of natural rubber in the world market [22]. Third, in terms of productivity, Thailand has a much higher natural rubber productivity compared to Indonesia and Malaysia. The average productivity of Thailand's natural rubber in the period of 2001-2019 was 1.64 tonnes per hectare [23]. This value is almost 2 times greater than the productivity of Indonesian natural rubber which reached 0.83 tonnes per hectare, while Malaysia's natural rubber productivity was only able to reach 0.78 tonnes per hectare. Indonesia and Malaysia face the same challenge, namely the low productivity of natural rubber. This is because there are still many smallholders who use poor-yielding rubber clones which are considered easier and cheaper to use [24], [25]. The use of high-yielding clones is the main step that can be taken for Indonesia and Malaysia in order to increase the competitiveness of natural rubber commodity exports in the global market. 


\section{Conclusion}

Natural rubber exports by Thailand, Indonesia, and Malaysia are highly competitive in the global market. This can be seen from the RCA index value of each country which is greater than 4. In addition, the EPD indicator shows that the export position of Thailand's natural rubber commodity in the global market is included in the rising star category, while Indonesia and Malaysia are respectively included in the category a lost opportunity and retreat. The strong competitive RCA index and rising star position brought Thailand's natural rubber export performance to be the best compared to Indonesia's and Malaysia's. This is driven by increasing global demand for natural rubber commodities, high harvested areas and a positive trend of harvested areas, and high productivity of natural rubber in Thailand.

\section{References}

1. Trademap. "List of importing markets for a product exported by Indonesia, Thailand, Malaysia. Product: 400122 Technically specified natural rubber "TSNR," List of Importing Market. (2021). [Online] from https://www.trademap.org/. [Accessed on 21-Mar-2021].

2. M. Frenkel and L. Zimmermann. Int. J. Manag. Econ. 56, 2:99-108(2020).

3. D. Sattayawaksakul and S. Y. Choi. A comparative analysis of export competition in natural rubber among the leading exporters in Southeast Asia. SSRN, 1, 1:19(2017).

4. R. Kamaludin. SIJDEB. 2, 1:85-98(2018).

5. F. Zuhdi and R. S. Anggraini. Int. J. Agric. Syst. 8, 2:130-139(2020).

6. P. Daulika, K.-C. Peng, and N. Hanani. Agric. Soc. Econ. J. 20, 1:39-44(2020).

7. M. A. Abtew. Int. J. Bus. Econ. Res. 4, 5:229-237(2015).

8. P. Bedi. Focus J. Int. Bus. 3, 2:58-87(2016).

9. S. French. J. Int. Econ. 106, 2017:83-103(2017).

10. R. Stellian and J. Danna-Buitrago. J. Appl. Econ. 22, 1:349-379(2019).

11. A. Gibba. Int. J. Sci. Technol. Res. 6, 05:8-15(2017).

12. A. Torok and A. Jambor. Agric. Econ. (Czech Republic). 62, 10:471-481(2016).

13. B. G. Hailay. J. Econ. Coop. Dev. 38, 1:55-96(2017).

14. S. Jagdambe. Foreign Trade Rev. 54, 1:16-28(2019).

15. B. Erkan and K. Saricoban. Int. J. Bus. Soc. Sci. 5, 8(1):117-130(2014).

16. M. A. Wardani, S. Mulatsih, and W. Rindayati. Etikonomi. 17, 2:185-198(2018).

17. R. L. Kusuma and M. Firdaus. J. Manaj. dan Agribisnis. 12, 3:226-236(2015).

18. L. Yanti and Widyastutik. J. Manaj. Agribisnis. 9, 3:183-193(2012).

19. E. S. Luhur, S. Mulatsih, and E. Puspitawati. Signifikan J. Ilmu Ekon. 8, 1:105120(2019).

20. N. Mdludin, S. Applanaidu, and H. Abdullah. Int. J. Environ. Agric. Res. 2, 6:2937(2016).

21. Knoema. Malaysia's Natural Rubber Harvested Area," Malaysia's Natural Rubber Harvested Area. [Online] from https://knoema.com/FAOPRDSC2020/productionstatistics-crops-crops-processed?tsId=1208640. (2021). [Accessed on 28-Jun-2021].

22. S. Yusoff, Z. Mohammed, and A. Z. Ahmad. Clim. Chang. Agric. 1, 1:1-14(2019).

23. FAO. Natural Rubber Statistics. FAOSTAT: Crop Statistics. [Online] from http://www.fao.org/faostat/.(2021) [Accessed on 21-Mar-2021].

24. Springfield Centre. Case Study: Rubber in Indonesia. Australia(2020).

25. I. Abdulla and F. M. Arshad. Outlook Agric. 46, 1:28-35(2017). 